\title{
Effects of hive spacing, entrance orientation, and worker activity on nest relocation by honey bee queens*
}

\author{
Juan Antonio PereZ-SATo ${ }^{1,2}$, William O.H. Hughes ${ }^{1,3}$, Margaret J. Couvillon ${ }^{1,4}$, \\ Francis L.W. RATNIEKS ${ }^{1,5}$
}

\footnotetext{
${ }^{1}$ Department of Animal and Plant Sciences, University of Sheffield, Western Bank, Sheffield, S10 2TN, UK

${ }^{2}$ Present address: Colegio de Postgraduados Campus Cordoba, Km 348 Carretera Federal Cordoba-Veracruz, Congregación Manuel Leon Amatlan de los Reyes, Cordoba, Veracruz, C.P. 94946, Mexico

${ }^{3}$ Present address: Institute of Integrative and Comparative Biology, University of Leeds, Leeds, LS2 9JT, UK

${ }^{4}$ Present address: Department of Ecology and Evolutionary Biology, University of Arizona, Tucson, Arizona, 85721, USA

${ }^{5}$ Present address: Laboratory of Apiculture and Social Insects, Department of Biological and Environmental Science, University of Sussex, Falmer, Brighton, BN1 9QG, UK
}

Received 18 April 2008 - Revised 16 August 2008 - Accepted 2 September 2008

\begin{abstract}
The mating flight is the riskiest period in the life of a honeybee queen. A major cause of queen mortality in apiaries may be the drifting of queens to foreign colonies. We investigated the effects of distance between hives, entrance orientation and worker activity on queen drifting. Only $4 \%$ of queens drifted in our experiments, all during their maiden orientation flight and all to the closest neighbouring hive. Neither drifting nor the length of time it took queens to relocate their hive was significantly affected by either entrance orientation or distance between hive stands ( $2 \mathrm{~m}$ or $5 \mathrm{~m}$ ). However, queens took significantly longer to identify their hive and were more likely to drift when the number of workers at the entrance was lower than that at the neighbouring hive. Our results show that drifting can be low even when hives are placed in pairs with only $2 \mathrm{~m}$ between pairs, and that worker activity has an important role in guiding returning queens on their maiden orientation flight.
\end{abstract}

\section{Apis mellifera mellifera / mating nucleus hive / mating flight / queen rearing / queen drifting}

\section{INTRODUCTION}

Beekeepers who rear honeybee queens commercially typically manage large numbers of mating 'nucleus' hives in special mating apiaries in order to produce large numbers of mated queens. Queens typically mate when 3-14 days of age, making one or two orientation flights followed by one to five mating flights (Lensky and Demter, 1985; Winston, 1995; Koeniger and Koeniger, 2008). During this period there can be a significant loss of queens, approximately 15-20\% under

Corresponding author: W.O.H. Hughes, w.o.h.hughes@leeds.ac.uk

* Manuscript editor: David Tarpy commercial queen rearing conditions (Laidlaw and Page, 1979; Palmer and Oldroyd, 2000; Medina and Gonçalves, 2001). One factor that is thought to be important in queen loss is the 'drifting' of a returning queen to a foreign hive in the apiary. Such mistakes are almost always fatal because workers kill any alien queens that they detect (Ribbands, 1953).

Beekeepers follow various recommendations to reduce drifting by aiding queens to relocate their colonies. Entrances of mating hives may be placed at different heights, close to orientation landmarks such as trees and bushes, or painted with different colours or patterns (Free, 1958; Ruttner, 1983; Medina and Gonçalves, 2001). Two of the most 
important recommendations are to arrange hives in pairs or irregular groupings with the entrances facing in different directions, and to ensure groups of hives are separated by at least 2-3 m (Laidlaw and Page, 1979; Ruttner, 1983). However, many apiaries have insufficient space for such strategies and it is often necessary to place mating nuclei in a straight row and/or close together. It seems likely that these practices will significantly increase the frequency of queen drifting, but their precise impact is unknown.

Here we examine the effects of the spacing and orientation of mating nucleus hives on queen drifting. We also investigated the previously unconsidered potential role of workers in the relocation of hives by queens. The results show that drifting was rare, even when hives were close together with entrances facing in the same direction. However, worker activity at the hive entrance did have a significant effect on the relocation of hives by queens.

\section{MATERIALS AND METHODS}

The study was carried out in a mating apiary at Losehill Hall, Derbyshire, England, during July and August 2005. Eighty honeybee mating nuclei were used, and the experiment was then repeated so that the flights of 160 queens were observed in total. The honeybees used were a mixture of European subspecies, but predominantly Apis mellifera mellifera Linnaeus. Each mating nucleus had 5 mediumdepth Langstroth combs (hive volume ca. $15 \mathrm{~L}$ ) and sufficient bees to cover 1-2 combs. Five days before the start of each set of observations, a 4day old virgin queen was introduced into each hive (Pérez-Sato et al., 2007). If a queen was rejected then a second was introduced. To allow identification, each queen was marked with a unique numbered tag (Opalithplättchen) on the notum.

Mating hives were set up in pairs, in a line $3 \mathrm{~m}$ from the hedge bordering the western boundary of the field (Fig. 1a). Each pair was placed on a hive stand approximately $30 \mathrm{~cm}$ above the ground to facilitate observation. Following standard beekeeping practice, the fronts of the hives within each pair were painted with different colours in order to provide orientation cues to returning bees (Fig. 1b). The nuclei were divided into four groups of 10 pairs. The first and third groups were positioned with $2 \mathrm{~m}$ between pairs, while the second

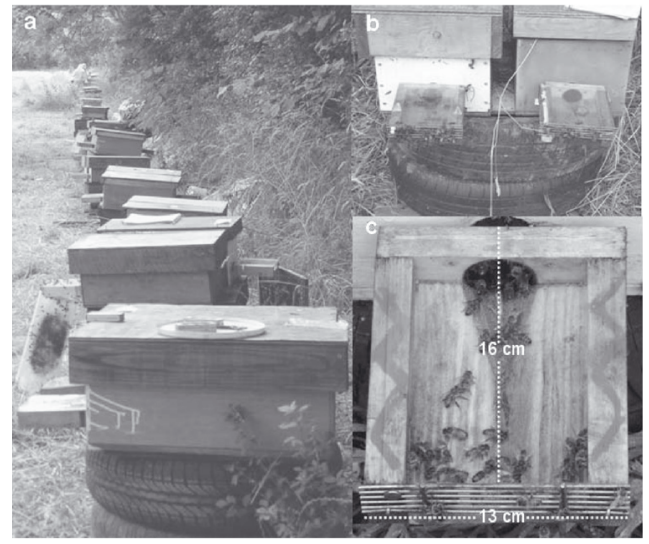

Figure 1. Mating nucleus hives were set up in a line $3 \mathrm{~m}$ from the field boundary at the Losehill Hall apiary (a). A pair of mating hives on a hive stand (two car tyres) with their entrances facing in the same direction (b). Apparatus mounted on the hive entrance to trap queens on leaving and returning from their flights (c).

and fourth groups had $5 \mathrm{~m}$ between pairs. An empty pair of nucleus hives was placed at either end of each group in order to ensure that the final pairs in each group were at the appropriate distances between pairs. The orientations of the entrances of the mating nuclei were alternated with one pair having entrances facing in the same direction and the next pair having entrances facing in opposite directions.

Observations of queen flights were made by five observers who patrolled the line of hives on days with good weather. In order to allow queen flights to be monitored, each hive had an apparatus mounted on the entrance to trap queens on leaving and returning (Fig. 1c). Each entrance was checked frequently, approximately every 5 minutes, during the period when queen mating flights occur in this area (1300 to $1700 \mathrm{~h}$ British Summer Time). When an exiting queen was observed within the entrance apparatus, the glass lid was removed to allow her to leave and to carry out either an orientation or mating flight. After she had taken flight, the glass lid was replaced. When the queen returned, she was observed either hovering in the vicinity of the hive or walking on the queen excluder material of the entrance apparatus. The glass lid was then removed to allow her to re-enter the hive. Queens were considered to have drifted if they were observed to land on the excluder of the entrance apparatus of a foreign hive. We observed the first flights of all 
160 queens, and also some second and third flights. Often, queens hovered for a period of time in front of or in the vicinity of their own hive or a foreign hive entrance box before landing. For 193 random flights, the length of time the queen spent hovering was recorded. To assess the relationship with worker activity, photos of the entrance boxes of pairs of mating hives were taken immediately after the queen had returned from her flight and the numbers of workers at the entrances later counted. This was done for all of the queens that drifted and for 44 randomly selected pairs of hives from which queens did not drift.

Drifting frequencies were compared between nuclei of different spacing and entrance orientation using Fisher's Exact Tests. The lengths of time that queens spent hovering when they returned from their flights were $\log (x+1)$ transformed and then analysed with general linear models. In addition, the numbers of worker bees present at the entrances of hives were examined. As drifting was always to the other hive in a pair, we specifically compared the numbers of workers at the entrances of the hives of queens who had returned from a flight with the neighbouring hive on the hive stand using a $t$-test. This was done separately for the hives from which the queen did or did not drift. Finally, the relationships between the length of time spent hovering and the numbers of workers at the entrances were examined with Pearson's correlation coefficients for the maiden and second flights of queens.

\section{RESULTS}

In total, 7 of 160 queens $(4.4 \%)$ were observed to drift to a foreign colony. All drifting was by queens on their maiden orientation flight and was to the other hive in the pair. There was no effect on drifting of the spacing between pairs of hives, with 4/80 queens (5\%) drifting when hive pairs were spaced $2 \mathrm{~m}$ apart and 3/80 (4\%) when they were $5 \mathrm{~m}$ apart $(P=1)$. Queens drifted slightly more often when the hive entrances within the pair were facing in the same direction $(5 / 80 ; 6 \%)$ than when they were facing in the opposite direction $(2 / 80 ; 3 \%)$. However, the extreme rarity of drifting meant the analysis had little power and the difference was not statistically significant $(P=0.608)$. There was also no effect of hive orientation $\left(F_{1,191}=0.361, P=0.549\right)$ or spacing $\left(F_{1,191}=0.003, P=0.953\right)$ on

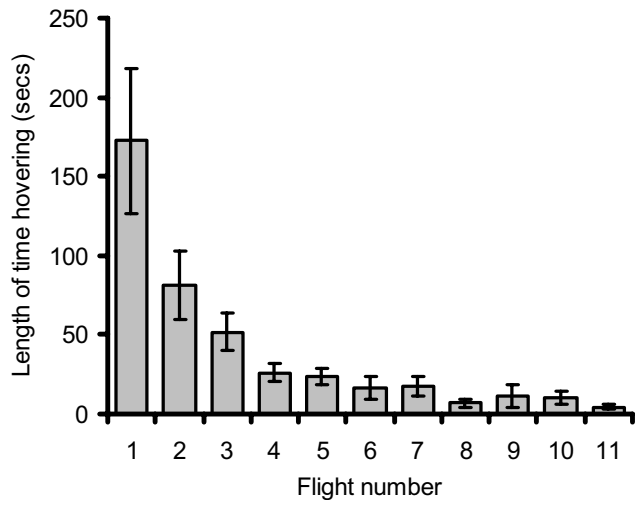

Figure 2. Mean ( \pm s.e.) length of time that queens spent hovering in the vicinity of their hives after returning from their maiden or subsequent flight.

the length of time queens spent hovering in the vicinity of their hive after returning from their flights. However, returning queens spent significantly more time hovering after their first flights than subsequent flights both in general $\left(F_{10,182}=7.64, P<0.001\right)$, and in particular after their maiden flight compared with their second or third flights $\left(F_{2,78}=6.27\right.$, $P=0.003$; Fig. 2).

For queens on their maiden flight that successfully returned to their own hive without drifting, the average number of workers present at the entrance of their hive was significantly greater than at the neighbouring hive ( $t=5.67$, df $=86, P<0.001$; Fig. 3$)$. In contrast, when the queen drifted to the neighbouring hive this relationship was reversed, with there being significantly fewer bees at the entrance of the hive from which the queen flew than the neighbouring hive $(t=-2.3$, df $=$ $12, P=0.04$; Fig. 3 ). There was a significant negative correlation between the number of worker bees present at the hive entrance and the length of time that the queen spent hovering before landing after her maiden flight ( $r=-0.807, \mathrm{n}=19, P<0.001$; Fig. 4). This correlation was not present for queens on their second flights $(r=-0.408, \mathrm{n}=14, P=0.148$; Fig. 4). 


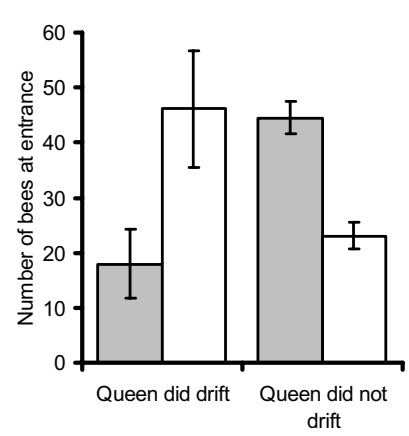

Figure 3. Mean ( \pm s.e.) number of worker bees present on the entrance apparatus of hives from which the queen was had flown (grey bar) versus the neighbouring hive (white bar). Data are from the maiden flights of queens and are presented separately for hives where the queen either did (left hand columns) or did not (right hand columns) drift.

\section{DISCUSSION}

Only 7 out of 160 queens (4\%) in our study drifted to other hives when they returned from a flight. This was in spite of the experiment being carried out with hives in close proximity and in a single row. All drifting was to the paired hive on the same hive stand and the spacing of $2 \mathrm{~m}$ or $5 \mathrm{~m}$ between pairs of hives, therefore, did not impact the probability of drifting. More surprisingly, the orientation of hive entrances within a pair (facing the same or opposite directions) also did not significantly affect drifting. Slightly more queens drifted when entrances were facing in the same direction $(6 \%)$ than in the opposite direction $(2.5 \%)$, but the overall rarity of drifting meant this was not statistically significant. Further support for the relative lack of importance of spacing or orientation comes from the much larger dataset on hovering times. It seems extremely reasonable that the length of time a queen spends hovering near her hive after returning from a flight is a direct measure of the difficulty she has in identifying her hive, and this was unaffected by either hive spacing or orientation. Importantly, the fronts of hives in our experiment were painted different colours within pairs. This has been recommended previously as a method of reducing queen drifting (Medina and Gonçalves, 2001), and is based on the well established importance of

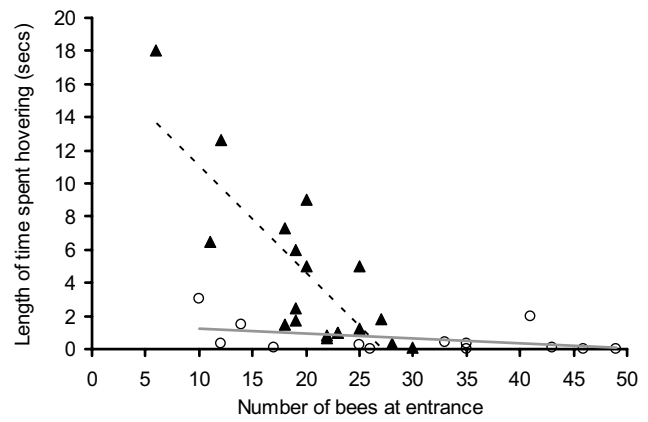

Figure 4. Relationships between the number of worker bees at the entrances of hives from which a queen had flown and the length of time that the queen spent hovering before landing after returning from her flight. Data are for the maiden flight (black triangles and dashed line, $y=-0.648 x+17.5)$, and the second flight (open circles and grey line, $y=$ $-0.03 x+1.5)$.

orientation landmarks and cues in enabling honeybees to relocate their hives (von Frisch, 1967; Winston, 1995; Capaldi and Dyer, 1999; Capaldi et al., 2000). Although we did not test the effect of colour ourselves, it is possible that the different colours of hives within pairs may in part explain the relative low rates of drifting we observed compared with other studies (Laidlaw and Page, 1979; Palmer and Oldroyd, 2000; Medina and Gonçalves, 2001). Regardless, our results show that, at least under the conditions in our experiment, drifting can be minimal even when hives are placed in pairs with only $2 \mathrm{~m}$ between pairs, and regardless of spacing or orientation.

All of the drifting that did occur was on the maiden orientation flight. Queens on later flights never drifted. Furthermore, queens on early flights, particularly the maiden flight, spent significantly longer hovering in the vicinity of their hive suggesting that they found the hive harder to identify or were learning its location, or both. During their early flights, honeybee workers and queens learn fine-grained details of the area near to their hive in order to allow them to relocate it (Lensky and Demter, 1985; Winston, 1995; Capaldi and Dyer, 1999; Capaldi et al., 2000). The zero drifting and lower hovering times of queens on later flights illustrate the 
effectiveness of this learning process. Once the necessary orientation cues have been learned, honeybee queens are able to relocate their hive extremely rapidly and with a $100 \%$ success rate, even when hives are in close proximity.

A novel finding from our study was the importance of worker activity in facilitating hive relocation by queens. Drifting was strongly related to the number of workers at the hive entrance. For queens that did not drift, there were significantly more workers at the entrance of the queen's own hive than at the other hive in the pair. However, the opposite pattern was observed when the queen drifted. Similarly, there was a significant negative correlation between the number of workers at the hive entrance and the length of time that queens spent hovering near the hive after returning from their maiden flight. The workers present at the hive entrances include departing and returning foragers, guard bees, and some scent fanning workers releasing orientation (Nasonov) pheromone (Winston, 1995). This pheromone is commonly released by workers at the hive entrance, especially when they have had difficulty finding the hive entrance (Ferguson and Free, 1981). Workers also release Nasanov pheromone following the departure of a queen on a flight (Ferguson and Free, 1981; Ruttner, 1983; Lensky and Demter, 1985; Winston, 1995). The size of mating nuclei were approximately standardised at the start of the experiment, so it is uncertain why hives differed so markedly in worker activity. However, it appears that the strength of the worker activity at the entrance in general, and most probably of Nasanov pheromone in particular, relative to neighbouring hives is extremely important in enabling a queen to relocate her hive following her maiden flight.

Our results provide important information on the drifting of honeybee queens relevant to commercial queen rearing and beekeeping in general. We found that drifting is not necessarily a significant problem even when hives are placed in a single row, in pairs on hive stands in relatively close proximity $(2 \mathrm{~m})$ and with entrances facing in the same direction. Our experiment differed from conditions in some mating apiaries, in having hive density no greater than hives in pairs with $2 \mathrm{~m}$ be- tween pairs, and hive fronts different colours within pairs. It seems likely that these details may, at least in part, be the reasons why the drifting rates we observed were very low compared to those recorded in commercial apiaries with much greater hive density (Laidlaw and Page, 1979; Palmer and Oldroyd, 2000; Medina and Gonçalves, 2001). In addition, the slightly greater rate of drifting we observed when hives were facing the same direction suggests that orientating neighbouring hives in opposite directions would be prudent. In addition, care should be taken to have nuclei of approximately equal strength on a hive stand in order to minimise the risk of neighbouring hives having greater worker activity during the maiden flights of queens. Accordingly, strong hives, such as those used for honey production, should also probably be excluded from the immediate vicinity (i.e. next to or on the same hive stand) of mating nucleus hives.

\section{ACKNOWLEDGEMENTS}

We thank Losehill Hall for providing the apiary site, and Alex Ball, Daniel Bradshaw, Jon Carruthers, Lucy Friend, Lyndsey Hudson, Hannah Tidbury, Ed Venison, Henrietta Wedmore, and Kenny Wintle for assistance in the field. J.A.P.-S. was supported by a Ph.D. scholarship from CONACyT (Mèxico), M.J.C. by a Ph.D. scholarship from the National Science Foundation (USA), and W.O.H.H. by a Marie Curie Outgoing International Fellowship within the 6th European Community Framework Programme.

Influence de l'espacement des ruches, de l'orientation de l'entrée et de l'activité des ouvrières sur la dérive des reines d'abeilles (Apis mellifera).

Apis mellifera mellifera /nucleus de fécondation / vol d'accouplement / élevage de reine / orientation / dérive / reine

Zusammenfassung - Einfluss von Beutenabstand, Fluglochausrichtung und Bienenaktivität auf den Verflug von Honigbienenköniginnen. Der Hochzeitsflug ist der risikoreichste Lebensabschnitt einer Bienenkönigin und Königinnenverluste während des Fluges können erhebliche Auswirkungen auf einen Königinnenzucht-Betrieb haben. Eine der Hauptursachen für Verluste dürfte 
die „Verdriftung“ von Königinnen in fremde Bienenvölker sein, bedingt durch die unnatürlich hohe Bienendichte an vielen Bienenständen. Wir untersuchten den Einfluss von Abstand zwischen den Bienenkästen, Ausrichtung des Flugloches und Aktivität der Arbeitsbienen auf die Verdriftung von Bienenköniginnen. Die Bienenaktivität wurde relativ zu benachbarten Völkern gemessen, wobei ein- und ausfliegende Königinnen über eine modifizierte Fluglochkonstruktion gefangen wurden. Die Experimente wurden unter typisch imkerlichen Bedingungen durchgeführt mit paarweise aufgestellten Bienenbeuten in Reihenaufstellung. Insgesamt verflogen sich nur $4 \%$ der Königinnen, alle während ihres Jungfernfluges. Weder der Verflug noch die Dauer für das Wiederfinden des eigenen Nestes wurde signifikant durch die Fluglochausrichtung (gleiche bzw. entgegen gesetzte Richtung) oder den Bienenvolkabstand ( $2 \mathrm{~m}$ bzw. $5 \mathrm{~m}$ zwischen den Bienenkästen) beeinflusst. Einen signifikanten Effekt hatte allerdings die Anzahl der Arbeiterinnen am Eingang der Bienenbeute. Die Völker, bei denen sich die Königinnen verflogen, hatten signifikant weniger Arbeiterinnen am Nesteingang als die direkt benachbarten Völker. Wenn die Anzahl der Arbeiterinnen geringer war, schwebten die Königinnen auch signifikant länger vor dem Flugloch ihrer Beute, vermutlich weil sie Schwierigkeiten hatten, ihre eigene Beute sicher zu identifizieren. Dies war allerdings nur beim Jungfernflug der Fall, nach mehreren Flügen hatten die Königinnen offensichtlich ihren Neststandort gelernt. Unsere Ergebnisse zeigen, dass Verflug von Königinnen nicht notwendigerweise ein Problem sein muss, selbst wenn die Bienenkästen eng zusammen und in Reihe mit gleicher Fluglochausrichtung aufgestellt werden. Unsere Ergebnisse zeigen auch, dass die Aktivität der Arbeiterinnen eine wichtige Rolle dabei spielt, Königinnen nach ihrem Jungfernflug ins eigene Nest zu lotsen. Daher könnte der Verflug minimiert werden, wenn man am selben Bienenstand Begattungseinheiten mit ähnlich großer Bienenpopulation aufstellt.

\section{Apis mellifera mellifera / Begattungskästchen / Hochzeitsflug / Königinnenaufzucht / Königin- nenverflug}

\section{REFERENCES}

Capaldi E.A., Dyer F.C. (1999) The role of orientation flights on homing performance in honeybees, J. Exp. Biol. 202, 1655-1666.

Capaldi E.A., Smith A.D., Osborne J.L., Fahrbach S.E., Farris S.M., Reynolds D.R., Edwards A.S., Martin A., Robinson G.E., Poppy G.M., Riley J.R. (2000) Ontogeny of orientation flight in the honeybee revealed by harmonic radar, Nature 403, 537540 .

Ferguson A.W., Free J.B. (1981) Factors determining the release of Nasonov pheromone by honeybees at the hive entrance, Physiol. Entomol. 6, 15-19.

Free J.B. (1958) The drifting of honeybees, J. Agric. Sci. 51, 294-306.

Frisch K. von (1967) The dance language and orientation of bees, Harvard Univ. Press, Cambridge, MA.

Koeniger N., Koeniger G. (2008) Mating flight duration of Apis mellifera queens: As short as possible, as long as necessary, Apidologie 38, 606-611.

Laidlaw H.H., Page R.E. (1979) Queen rearing and bee breeding, Wicwas Press, Cheshire, Conneticut.

Lensky Y., Demter M. (1985) Mating flights of the queen honeybee (Apis mellifera) in a sub-tropical climate, Comp. Biochem. Physiol. A Physiol. 81, 229-241.

Medina L.M., Gonçalves L.S. (2001) Effect of weight at emergence of africanzied (Apis mellifera L.) virgin queens on their acceptance and beginning of oviposition, Am. Bee J. 141, 213-215.

Palmer K.A., Oldroyd B.P. (2000) Evolution of multiple mating in the genus Apis, Apidologie 31, 235 248.

Pérez-Sato J.A., Hughes W.O.H., Couvillon M.J., Ratnieks F.L.W. (2007) Improved technique for introducing four-day old virgin queens to mating hives that uses artificial and natural queen cells for introduction, J. Apic. Res. 46, 28-33.

Ribbands C.R. (1953) The behaviour and social life of honeybees, Bee Research Association Limited, London, England.

Ruttner F. (1983) Queen rearing: biological basis and technical instructions, Apimondia Publishing House, Bucharest, Romania.

Winston M.L. (1995) The biology of the honey bee, Harvard University Press, London. 